Dr. YELLOWLmes asked if there was any kind of security that the 43. was given to the right person, or that the patients boarded out or handed over to relatives were properly oared for. There seemed to be some want of maohinery for working it. In Scotland the patients were regularly visited and the houses licensed, and so the sum of money spent through the Guardians was properly spent. Without some such check he did not know how they rould at all secure that the patient should get the benefit of the money. He moved the addition of the words, "And for patients similarly discharged from asylums to the care of relatives and others."

The amendment was not seconded.

The substantive motion was then agreed to.

Dr. OAMPBaLl moved : "That a copy of this resolution be sent by the General Secretary to the President of the Local Government Board and to the Commiesioners in Lunacy, asking them to assist in carrying the terms of the resolntion into effect."

Dr. Crapuan seconded the resolution, which was agreed to.

Obituary.

WILLIAM RHYS WILLIAMS, M.D.,

Late Commissioner in Lunacy and former Superintendent, Bethlem Royal Hospital.

We regret that it is our duty to have to record the premalure death of our former member and friend Dr. Rhys Williams, which occurred in the first week of Decenber, 1893. Dr. Williams was 56 when he diod, and he had had, as we shall point out later, an unusually wide experience of lunacy in all its relations. Hecame of a family of doctors; his father was a much respected physioian, who was in practice at Nottingham, where he was visiting physician to the asylum.

Williams was sent to Merchant Taylor's school, where he took a high position, winning a classical scholarship on lesving the school, which gained him entrance to St. Thomas' Hospital. This was most opportune, for his father had then been recently killed by a carriage accident. At the hospital he was a very quiet, steady, painstaking student, who impressed his teachers very favourably. He qualified as quickly as possible, as it was necessary for him at once to earn money. For about 18 months he acted as assistant to a general practitioner at Daventry. Here he got his practical knowledge of the smaller ailments and their remedies, which he always used to say stood him in suoh good stead in after life. Here, too, he exhibited his power for winning the affection of his patients. After this he began his real work in lunaoy by becoming assistant medical officer at the Derby County Asylum. Thenoe he went to assist Dr. Willett, at Wyke House, and it soemed as if Williams had settled into a groove for which he was eminently well suited; the country life, the hanting, and the genial social surroundings saited him well, bat he threw up this to join once more the publio service, and he was selected assistant medical officer to the T'hree Counties Asylum, under the late Dr. Denne. This part of his life he was very fond of recalling with pleasure as the one during which he learnt the administrative part of his work. Williams got to know the new Treasnrer (Sir C. Hood) of Bethlem through his connection with Dr. Willett, and this, in addition to other valuable introductions, led to his seloction as assistant physician to Bethlem.

Soon after his appointment his senior, Dr. Helps, broke down in health and was ordered abroad, and thus for over a year Williams had almost the entire 
work of the hospital on his shoulders. For weeks together he never passed the gates, and he did his work in such a satisfactory way that on the dealh of his senior he was selected as Superintendent over the heads of many senior men. We are inclined to think this was rather a misfortune for Williams, and that the too early attainment of the end removed the incentive to work. He was always devotedly attached to and proud of the hospital, and to all belonging to it. There were two very important steps taken soon after his appointment, the one being the institution of clinical assistants, and the other being the opening of the Convalescent Home at Witley; both these steps have been followed by other institutions. While at Bethlem the most conspicuous point about him was the personal affection be won from the patients under his care and from their friends. His free and genial manner made him almost too great a farourite for his comfort or for his real good.

The late Lord Shaftesbury was among those who were very favourably struck by him, and the resalt was the offer of a Commissionership. This he accepted, and began his work at once in 1878 , and for ten years he held the post, retiring in 1889. His friends having for some time noticed signs of failing health were not surprised at his resignation. As Commissioner he was kindly and considerate to all, and nothing gave him greater pleasure than being reoognized by old Bethlem patients who had fornerly been under his care. On his resignation he went to Leamington, where he placidly and happily lived with his sister, who devoted herself to his care.

Early in December he was attacked with bronchitis, which terminated fatally in a few days, and thus ended the life of one who, with more than average ability and with an unuscal capacity of attracting friends, might have left a bigger mark on his time and in his profession if he had not reached his gosl too soon.

\section{ISAAC N. KERLIN, M.D.}

The death, on October 25th, of Dr. Kerlin, so well known, both in Europe and America, as the earnest and successful Superintendent of the Pennsylvania Institution for Feeble-Minded Children, removes from the scene of his labours one of the most energetic benefactors of the imbecile class.

Dr. Kerlin was born in New Jersey nearly sixty years ago. Early in his medical career he became interested in nervous diseases, and naturally drifted into the special line of study which led him to assume the position he so long held. After some years' service as Assistant Superintendent under Dr. Joseph Parrish, he succeeded that physician as Superintendent of the Pennsylvania Institution (then at Germanstown) in 1864. Year by year, under his judicious guidance, the institution grew and prospered; and from two small buildings, with less than 100 pupils, gradually developed the large establishment that now exists at Elwyn, which indeed may be designated a model village for the various classes of imbeciles, numbering in all upwards of 1,000. Here may be seen, picturesquely placed on wooded eminences, the several departments into whioh a large establishment for imbeciles groups itself, the central training school being the most prominent, and, subsidiary to this, at discreet distances, are found a hospital, a department for epileptics, and separate blocks for custodial cases of either sex. These several buildings are connected by means of a mule-car tramway, shares in which Dr. Kerlin used to suggest as a good investment to the benevolent! One of the special features of the beautiful grounds is the "Grove Tabernacle," where on summer evenings from 600 to 700 of the asylum family gather for Sabbath worship under the spreading forest trees. But the heart and soul of the organization was the good doctor himself. Living in 